\title{
Analysis of Factors Affecting the Decision of the JABODETABEK Community in Using Equity Crowdfunding Platform
}

\author{
Fauzan Nasafi ${ }^{\mathrm{a}}$ and Emil Robert Kaburuan ${ }^{\mathrm{b}}$ \\ a,b Information System Management Department, BINUS Graduate Program-Master of Information \\ System Management, Bina Nusantara University, Jakarta, Indonesia 11480
}

\author{
Article History: Received: 10 November 2020; Revised 12 January 2021 Accepted: 27 January \\ 2021; Published online: 5 April 2021
}

\begin{abstract}
This research analyzes the factors that influence the decision to use the equity funding platform in Indonesia. Equity crowdfunding platform is a platform that organizes the crowdfunding process, where investors will receive an equity instrument that provides a share of ownership or a share of future income. This research model is compiled based on the merging of previous research models related to the intention to use the equity funding platform, such as Financing Objectives, Number of Shares Assigned, Number of Inquiries, Familiarity with the Company or Its Product, Target Attractiveness and Campaign Specification. Sources of data were collected from respondents using the equity crowdfunding platform who are JABODETABEK people through a questionnaire, and obtained 428 respondents. The data were analyzed using the SmartPLS 3 , and the results show that the variable Familiarity with the Company or Its Product and Target Attractiveness affects people's decisions in using the equity crowdfunding platform.
\end{abstract}

Keywords: Equity crowdfunding, Equity crowdfunding Platform, Intention to Use, Financing Objectives, Number of Shares Assigned, Number of Inquiries, Familiarity/Experience with the Target Company or Its Product, Target Attractiveness, Campaign Specification.

\section{Introduction}

New companies will face difficulties in obtaining external funding from the company when the company is first established (Belleflamme et al., 2014). To get this funding, the company has challenges to convince investors to commit to this funding (Hellmann, 2007). Based on the analysis conducted by (Statistik, 2019), 80.07\% of SMEs in Indonesia need credit but cannot get credit, and $60.14 \%$ of SMEs stated that capital/liquidity is the main problem faced.

These constraints encourage the emergence of new methods of funding, one of which is through crowdfunding. The term "crowdfunding" comes from a more familiar term, namely "crowdsourcing", which describes a group of people who accumulate their assets, resources, knowledge or expertise (Hemer, 2011). Crowdfunding is an activity that involves general information, mostly via the internet, for the provision of financial resources either in the form of donations or in exchange for products or to support initiatives for specific purposes (Belleflamme et al., 2014).

With the development of a crowdfunding-based funding platform, it will have an impact on the progress of SMEs in Indonesia (Nugroho \& Rachmaniyah, 2019). However, the Indonesian people, especially those in urban society, still do not make full use of it (Nugroho \& Rachmaniyah, 2019). Although the number of active crowdfunding platforms in Indonesia (14) is more than the number of active crowdfunding platforms in Malaysia (9), in Malaysia the entrepreneurship rate is 5 percent of the total population compared to Indonesia which only reaches 3.1\% of Indonesia's population in 2018 (Nugroho \& Rachmaniyah, 2019)

Based on this background, especially with regard to the low utilization of funding facilities through crowdfunding and the large amount of credit/funding requirements for MSEs, the authors took the initiative to conduct research on what factors influence the JABODETABEK community's decision to use the equity crowdfunding platform. 


\section{Literature Review}

\subsection{Crowdfunding}

Crowdfunding can be simply defined as funding from many sources/parties, it can start from asking for capital assistance from family and friends which is then developed to the general public through the internet media (Adriansyah, 2016).

\subsection{Investor Motivation in Investing through Crowdfunding (Ferreira \& Pereira, 2018):}

- Financial Return. Get financial benefits on investments made through crowdfunding.

- Community Based Benefits. Investments made in this regard are active investments in a community/organization. So that investors can be involved in making decisions in a community/organization.

- To Help. This investment is made to the partner or family of the investor, so that the investment can provide assistance to the colleague or family

- To Support. Investors who make these investments based on their trust in the invested project can have an important impact on many people even though there is no profit for these investors

\subsection{Previous Research}

There is a difference between this study and previous research are research approach, research location and research variables (Li et al., 2018) was conducted on equity crowdfunding in China and (Lukkarinen et al., 2018) was conducted on equity crowdfunding in Northern Europe, including the United Kingdom. For research variables, this study combines several variables in the two studies such as financing objectives, number of shares assigned, number of inquiries, familiarity/experience with the target company or its product, target attractiveness, campaign specifications, awareness level about crowdfunding and financial return.

\section{Research Method}

Hypothesis testing in this study uses a Structural Equation Model based on PLS or Partial Least Square. Where the data will be processed using SmartPLS software. The survey was conducted by distributing questionnaires to the JABODETABEK community. Based on data obtained from the Regulation of the Minister of Home Affairs of the Republic of Indonesia Number 72 of 2019 concerning Amendments to the Regulation of the Minister of Home Affairs Number 137 of 2017 concerning Codes and Data for Government Administration Areas dated 25 October 2019, the total population in JABODETABEK is $29,116,662$ people. The sampling error rate was $5 \%$ and with a population of $29,116,662$, the number of samples used according to the Slovin formula was 400 respondents.

\subsection{Structural Model}

This research was conducted by analyzing the relationship between the dependent variable, namely $\mathrm{Y}$ and the independent variable, X. Where is the Financing Objectives (X1), Number of shares assigned (X2), Number of inquiries (X3), Familiarity/experience with the target company or its product (X4), target attractiveness (X5) and Campaign specification (X6) are independent variables with Intention to Use (Y) being the dependent variable. As can be seen in the following Figure 1.

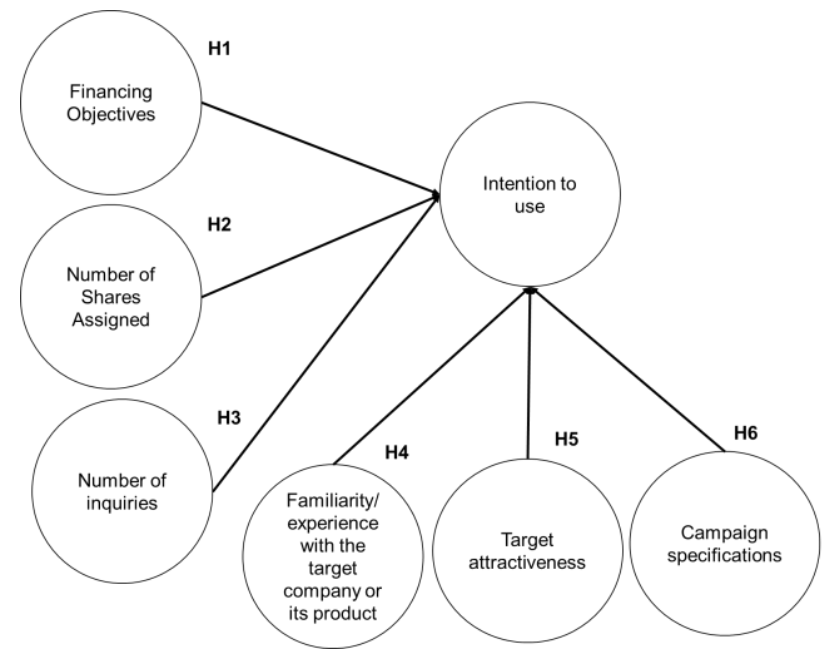

Figure 1. Structural Model Analysis 


\subsection{Variable Measurement and Hypothesis}

From that all variables, it requires indicators to describe these variables. These indicators and hypothesis are as documented in Table 1.

Table 1. Indicators for each variable

\begin{tabular}{|c|c|c|c|c|}
\hline No & Variables & Indicators & $\begin{array}{l}\text { Indicators } \\
\text { Code }\end{array}$ & Hypothesis \\
\hline 1 & \multirow{3}{*}{$\begin{array}{l}\text { Financing } \\
\text { Objectives } \\
\text { (X1) }\end{array}$} & $\begin{array}{l}\text { The bigger the funding target makes you confident in } \\
\text { making funding }\end{array}$ & FO1 & \multirow{3}{*}{$\begin{array}{l}\text { Financing } \\
\text { Objectives } \rightarrow \\
\text { Intention to } \\
\text { Use (Li et al., } \\
\text { 2018) }\end{array}$} \\
\hline 2 & & $\begin{array}{l}\text { The remaining amount of funding needed makes you } \\
\text { confident in making funding }\end{array}$ & FO2 & \\
\hline 3 & & $\begin{array}{l}\text { The greater the minimum amount of initial funding } \\
\text { required to make you confident in funding }\end{array}$ & FO3 & \\
\hline 4 & \multirow{3}{*}{$\begin{array}{l}\text { Number of } \\
\text { shares } \\
\text { assigned } \\
\text { (X2) }\end{array}$} & $\begin{array}{l}\text { The more shares that are distributed to investors, the more } \\
\text { confident you are in making funding }\end{array}$ & NSA1 & \multirow{3}{*}{$\begin{array}{l}\text { Number of } \\
\text { shares } \\
\text { assigned } \rightarrow \\
\text { Intention to } \\
\text { Use (Li et al., } \\
\text { 2018) }\end{array}$} \\
\hline 5 & & $\begin{array}{l}\text { The proportion of shares for each investor, makes you } \\
\text { confident in making funding }\end{array}$ & NSA2 & \\
\hline 6 & & $\begin{array}{l}\text { The number of shares distributed to investors, assures } \\
\text { you of the effectiveness of the funding opened }\end{array}$ & NSA3 & \\
\hline 7 & \multirow{3}{*}{$\begin{array}{l}\text { Number of } \\
\text { inquiries } \\
\text { (X3) }\end{array}$} & $\begin{array}{l}\text { The more potential investors ask about the funding } \\
\text { project, making you confident in funding }\end{array}$ & NI1 & \multirow{3}{*}{$\begin{array}{l}\text { Number of } \\
\text { inquiries } \rightarrow \\
\text { Intention to } \\
\text { Use (Li et al., } \\
2018 \text { ) }\end{array}$} \\
\hline 8 & & $\begin{array}{l}\text { The more information you are looking for related to } \\
\text { funding projects, the more confident you are in making } \\
\text { funding }\end{array}$ & NI2 & \\
\hline 9 & & $\begin{array}{l}\text { The more information provided related to funding } \\
\text { projects, the more confident you will be in funding }\end{array}$ & NI3 & \\
\hline 10 & \multirow{4}{*}{$\begin{array}{l}\text { Familiarity/ } \\
\text { experience } \\
\text { with the } \\
\text { target } \\
\text { company or } \\
\text { its product } \\
\text { (X4) }\end{array}$} & $\begin{array}{l}\text { You already know the company to be funded or its } \\
\text { product, making you confident in making funding }\end{array}$ & FTC1 & \multirow{4}{*}{$\begin{array}{l}\text { Familiarity/ } \\
\text { experience } \\
\text { with the } \\
\text { target } \\
\text { company or } \\
\text { its product } \rightarrow \\
\text { Intention to } \\
\text { Use } \\
\text { (Lukkarinen } \\
\text { et al., 2018) }\end{array}$} \\
\hline 11 & & $\begin{array}{l}\text { The company that is going to be funded or its product has } \\
\text { a lot of advertising circulating, making you confident in } \\
\text { making funding }\end{array}$ & FTC2 & \\
\hline 12 & & $\begin{array}{l}\text { You are already using products from companies that will } \\
\text { be funded for a long time, making you confident in } \\
\text { making funding }\end{array}$ & FTC3 & \\
\hline 13 & & $\begin{array}{l}\text { The products of the company to be funded are } \\
\text { recommended by many people, making you confident in } \\
\text { making funding }\end{array}$ & FTC4 & \\
\hline 14 & \multirow{4}{*}{$\begin{array}{l}\text { Target } \\
\text { attractiveness } \\
\text { (X5) }\end{array}$} & $\begin{array}{l}\text { The company's financial history of the company that will } \\
\text { be funding will make you confident in making funding }\end{array}$ & TA1 & \multirow{4}{*}{$\begin{array}{l}\text { Target } \\
\text { attractiveness } \\
\rightarrow \text { Intention } \\
\text { to Use } \\
\text { (Lukkarinen } \\
\text { et al., 2018) }\end{array}$} \\
\hline 15 & & $\begin{array}{l}\text { The bigger the market of the company to be funded will } \\
\text { make you confident in making funding }\end{array}$ & TA2 & \\
\hline 16 & & $\begin{array}{l}\text { The level of market expansion over time of the company } \\
\text { to be funded will make you confident in funding }\end{array}$ & TA3 & \\
\hline 17 & & $\begin{array}{l}\text { The company's financial target of the company to be } \\
\text { funded will make you confident in funding }\end{array}$ & TA4 & \\
\hline 18 & \multirow{3}{*}{$\begin{array}{l}\text { Campaign } \\
\text { specification } \\
\text { (X6) }\end{array}$} & $\begin{array}{l}\text { The amount of funds that have been invested by other } \\
\text { people in the company to be funded makes you confident } \\
\text { in making funding }\end{array}$ & $\mathrm{CS} 1$ & \multirow{3}{*}{$\begin{array}{l}\text { Campaign } \\
\text { specification } \\
\rightarrow \text { Intention } \\
\text { to Use } \\
\text { (Lukkarinen } \\
\text { et al., 2018) }\end{array}$} \\
\hline 19 & & $\begin{array}{l}\text { The number of investors needed to make funding makes } \\
\text { you confident in making funding }\end{array}$ & $\mathrm{CS} 2$ & \\
\hline 20 & & $\begin{array}{l}\text { The funding target amount makes you confident in } \\
\text { making funding }\end{array}$ & CS3 & \\
\hline 21 & \multirow{2}{*}{$\begin{array}{l}\text { Intention to } \\
\text { Use }(\mathrm{Y})\end{array}$} & $\begin{array}{l}\text { I will use the equity crowdfunding platform as my } \\
\text { investment medium }\end{array}$ & IU1 & \\
\hline 22 & & $\begin{array}{l}\text { I will often use the equity crowdfunding platform as my } \\
\text { investment medium }\end{array}$ & IU2 & \\
\hline
\end{tabular}




\begin{tabular}{|l|l|l|c|c|}
\hline No & Variables & \multicolumn{1}{|c|}{ Indicators } & $\begin{array}{c}\text { Indicators } \\
\text { Code }\end{array}$ & Hypothesis \\
\hline 23 & & $\begin{array}{l}\text { I will use the equity crowdfunding platform as my } \\
\text { investment medium, even though there are other } \\
\text { investment media }\end{array}$ & IU3 & \\
\hline
\end{tabular}

\subsection{Research Data Analysis}

In this study, data analysis was carried out through the analysis of the outer model and inner model as follows on Table 2.

Table 2. Model Test

\begin{tabular}{|c|c|c|c|}
\hline Model Test & \multicolumn{2}{|c|}{ Testing Type } & Parameter \\
\hline \multirow{7}{*}{$\begin{array}{l}\text { Outer Model } \\
\text { (Hair et al., } \\
\text { 2011) }\end{array}$} & \multirow[t]{3}{*}{ Formative } & Collinearity & VIF value <5 (Hair et al., 2011) \\
\hline & & \multirow{2}{*}{$\begin{array}{l}\text { External } \\
\text { Validity }\end{array}$} & Loading value $>0.70$ (Majchrzak et al., 2013) \\
\hline & & & $\begin{array}{l}\text { P-value of the outer weight }<0.05 \text { (Cenfetelli \& } \\
\text { Bassellier, 2015) }\end{array}$ \\
\hline & \multirow[t]{2}{*}{ Reflective } & Convergent & $\begin{array}{l}\text { AVE value of each latent construct }>0.50 \text { (Hair et al., } \\
\text { 2011) }\end{array}$ \\
\hline & & Discriminant & Fornell-Larcker >0.70 (Hair et al., 2011) \\
\hline & \multirow[t]{2}{*}{ Reliability } & & Composite Reliability value $<0.70$ (Hair et al., 2011) \\
\hline & & & Loading value $>0.70$ (Hair et al., 2011) \\
\hline \multirow{5}{*}{$\begin{array}{l}\text { Inner Model } \\
\text { (Henseler et } \\
\text { al., 2009) }\end{array}$} & $\begin{array}{l}\text { Coefficient of } \\
\text { Determination }\left(\mathrm{R}^{2}\right)\end{array}$ & & $\begin{array}{l}\text { R Square adjusted value } \rightarrow 0.25 \text { (Weak), } 0.50 \\
\text { (Moderate), } 0.75 \text { (Strong) (Hair et al., 2011) }\end{array}$ \\
\hline & $\begin{array}{l}\text { Predictive } \\
\text { Relevance }\left(\mathrm{Q}^{2}\right) \text {. }\end{array}$ & & Q Square value $>0$ (Hair et al., 2011) \\
\hline & \multirow[t]{3}{*}{ Reliability } & \multirow{3}{*}{$\begin{array}{l}\text { Path } \\
\text { Coefficient }\end{array}$} & Original sample $=0$ (Hair et al., 2011) \\
\hline & & & P Value <0.05 (Hair et al., 2011) \\
\hline & & & T-Statistic >1.96 (Hair et al., 2011) \\
\hline
\end{tabular}

\section{Result and Discussion}

Data collection in this study was carried out by distributing questionnaires online on Google Form. The questionnaire was distributed through instant messenger applications and social media. From the questionnaire, it was found that 535 respondents participated in filling out the questionnaire, but based on the question to test the validity of the respondents, namely "Have you ever used the Equity Crowdfunding Platform?", 107 respondents were eliminated because they answered "No" to the question to test the validity. So that the total respondents found were 428 respondents.

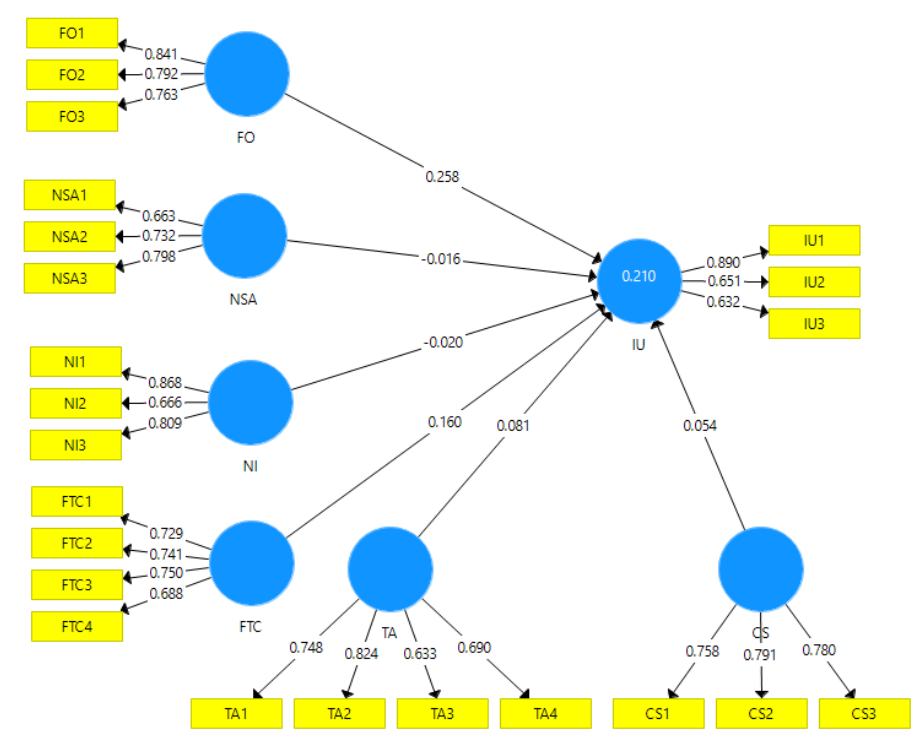

Figure 2. Analysis Result 


\subsection{Formative Measurement Model Test}

Table 3. Collinearity and External Validity Test Result

\begin{tabular}{|c|c|c|c|c|c|c|}
\hline \multirow[b]{2}{*}{ Indicator Variable } & \multirow[b]{2}{*}{ Indicator } & \multirow[b]{2}{*}{ VIF } & \multicolumn{2}{|c|}{ Initial conditions } & \multicolumn{2}{|c|}{ Final conditions } \\
\hline & & & $\begin{array}{c}\text { Loading } \\
(>0.70)\end{array}$ & $\begin{array}{l}\text { Weight } \\
(<0.05)\end{array}$ & $\begin{array}{c}\text { Loading } \\
(>0.70)\end{array}$ & $\begin{array}{l}\text { Weight } \\
(<0.05)\end{array}$ \\
\hline \multirow[t]{3}{*}{ Campaign Specification (CS) } & CS1 & 1.281 & 0.758 & 0 & 0.751 & 0 \\
\hline & CS2 & 1.306 & 0.791 & 0 & 0.775 & 0 \\
\hline & CS3 & 1.329 & 0.78 & 0 & 0.802 & 0 \\
\hline \multirow[t]{3}{*}{ Financing Objectives (FO) } & FO1 & 1.462 & 0.841 & 0 & 0.824 & 0 \\
\hline & FO2 & 1.418 & 0.792 & 0 & 0.823 & 0 \\
\hline & FO3 & 1.361 & 0.763 & 0 & 0.749 & 0 \\
\hline \multirow{4}{*}{$\begin{array}{l}\text { Familiarity/experience with the } \\
\text { target company or its product (FTC) }\end{array}$} & FTC1 & 1.34 & 0.729 & 0 & 0.777 & 0 \\
\hline & FTC2 & 1.286 & 0.741 & 0 & 0.734 & 0 \\
\hline & FTC3 & 1.36 & 0.75 & 0 & 0.786 & 0 \\
\hline & FTC4 & 1.304 & 0.688 & 0 & & \\
\hline \multirow[t]{3}{*}{ Intention of use (IU) } & IU1 & 1.168 & 0.89 & 0 & 1 & \\
\hline & IU2 & 1.308 & 0.651 & 0 & & \\
\hline & IU3 & 1.274 & 0.632 & 0.001 & & \\
\hline \multirow[t]{3}{*}{ Number of Inquiries (NI) } & NI1 & 1.337 & 0.868 & 0 & 0.827 & 0 \\
\hline & $\mathrm{NI} 2$ & 1.385 & 0.666 & 0.004 & 0.705 & 0 \\
\hline & NI3 & 1.493 & 0.809 & 0 & 0.836 & 0 \\
\hline \multirow[t]{3}{*}{ Number of Shares (NSA) } & NSA1 & 1.165 & 0.663 & 0 & & \\
\hline & NSA2 & 1.143 & 0.732 & 0 & 0.807 & 0 \\
\hline & NSA3 & 1.26 & 0.798 & 0 & 0.831 & 0 \\
\hline \multirow[t]{4}{*}{ Target Attractiveness (TA) } & TA1 & 1.41 & 0.748 & 0 & 0.806 & 0 \\
\hline & TA2 & 1.382 & 0.824 & 0 & 0.883 & 0 \\
\hline & TA3 & 1.252 & 0.633 & 0 & & \\
\hline & TA4 & 1.302 & 0.69 & 0 & & \\
\hline
\end{tabular}

From Table 3, it can be seen that all indicators have a VIF value of less than 5 , so these indicators can be used for external validity testing. In the external validity test, it was found that in the initial model all outer weight values were $<0.50$ but there were several indicators that had outer loading values below 0.70 , such as FTC4, IU2, IU3, NSA1, TA3 and TA4, so that these indicators were removed. After adjustments were made, all of these indicators had outer loading values $>0.70$ and outer weight $<0.50$, so that they passed the external validity test and passed the collinearity test.

\subsection{Reflective Measurement Model Test}

Table 4. AVE \& Forrel-Larcker Method Test Result (Final Condition)

\begin{tabular}{|l|l|l|l|l|l|l|l|l|}
\hline \multicolumn{2}{|c|}{ AVE Test Result } & \multicolumn{7}{c|}{ Forrel-Larcker Method } \\
\hline \multicolumn{1}{|c|}{ Variable } & AVE $(>\mathbf{0 . 5 0})$ & CS & FO & FTC & IU & NI & NSA & TA \\
\hline CS & 0.603 & 0.776 & & & & & & \\
\hline FO & 0.639 & 0.696 & 0.799 & & & & & \\
\hline FTC & 0.587 & 0.638 & 0.593 & 0.766 & & & & \\
\hline IU & 1 & 0.416 & 0.414 & 0.456 & 1 & & & \\
\hline NI & 0.627 & 0.653 & 0.609 & 0.684 & 0.345 & 0.792 & & \\
\hline NSA & 0.671 & 0.532 & 0.522 & 0.554 & 0.339 & 0.572 & 0.819 & \\
\hline TA & 0.714 & 0.563 & 0.534 & 0.587 & 0.446 & 0.592 & 0.499 & 0.845 \\
\hline
\end{tabular}

Table 5. Cross Loading (Final Condition)

\begin{tabular}{|l|l|l|l|l|l|l|l|}
\hline & CS & FO & FTC & IU & NI & NSA & TA \\
\hline CS1 & 0.751 & 0.467 & 0.431 & 0.302 & 0.437 & 0.365 & 0.413 \\
\hline CS2 & 0.775 & 0.604 & 0.508 & 0.32 & 0.511 & 0.424 & 0.463 \\
\hline CS3 & 0.802 & 0.548 & 0.543 & 0.346 & 0.565 & 0.447 & 0.437 \\
\hline FO1 & 0.544 & 0.824 & 0.464 & 0.347 & 0.463 & 0.391 & 0.444 \\
\hline FO2 & 0.556 & 0.823 & 0.535 & 0.36 & 0.524 & 0.423 & 0.453 \\
\hline
\end{tabular}




\begin{tabular}{|c|c|c|c|c|c|c|c|}
\hline & CS & FO & FTC & IU & NI & NSA & TA \\
\hline FO3 & 0.58 & 0.749 & 0.412 & 0.278 & 0.475 & 0.448 & 0.378 \\
\hline FTC1 & 0.48 & 0.443 & 0.777 & 0.347 & 0.532 & 0.445 & 0.472 \\
\hline FTC2 & 0.504 & 0.467 & 0.734 & 0.334 & 0.483 & 0.41 & 0.439 \\
\hline FTC3 & 0.485 & 0.453 & 0.786 & 0.365 & 0.554 & 0.42 & 0.44 \\
\hline \multicolumn{8}{|l|}{ FTC4 } \\
\hline IU1 & 0.416 & 0.414 & 0.456 & 1 & 0.345 & 0.339 & 0.446 \\
\hline \multicolumn{8}{|l|}{ IU2 } \\
\hline \multicolumn{8}{|l|}{ IU3 } \\
\hline NI1 & 0.515 & 0.516 & 0.544 & 0.317 & 0.827 & 0.463 & 0.475 \\
\hline NI2 & 0.495 & 0.449 & 0.553 & 0.176 & 0.705 & 0.474 & 0.384 \\
\hline NI3 & 0.552 & 0.485 & 0.553 & 0.295 & 0.836 & 0.447 & 0.53 \\
\hline \multicolumn{8}{|l|}{ NSA1 } \\
\hline NSA2 & 0.419 & 0.405 & 0.387 & 0.269 & 0.413 & 0.807 & 0.355 \\
\hline NSA3 & 0.452 & 0.449 & 0.518 & 0.286 & 0.521 & 0.831 & 0.459 \\
\hline TA1 & 0.476 & 0.427 & 0.513 & 0.33 & 0.523 & 0.483 & 0.806 \\
\hline TA2 & 0.48 & 0.475 & 0.487 & 0.417 & 0.486 & 0.376 & 0.883 \\
\hline TA3 & & & & & & & \\
\hline
\end{tabular}

Based on the Fornell-Larcker method in Table 4, it is known that each variable has a square root value of AVE that is greater than the correlating variables, so that these variables have passes convergent validity. In addition, as shown in Table 5, the indicators are also tested for discriminant validity using the Cross Loading method, it is known that each indicator has a greater value between one another, so that the indicators have passed the discriminant validity.

\subsection{Reliability Test}

Table 6. Internal Consistency Reliability \& Indicator Reliability Test Result (Final Condition)

\begin{tabular}{|c|c|c|c|}
\hline \multicolumn{2}{|c|}{ Internal Consistency Reliability } & \multicolumn{2}{|c|}{ Indicator Reliability } \\
\hline Variable & Composite Reliability $(>0.70)$ & Indicator & Loading $(>0.70)$ \\
\hline \multirow[t]{3}{*}{ Campaign Specification } & \multirow[t]{3}{*}{0.82} & CS1 & 0.751 \\
\hline & & CS2 & 0.775 \\
\hline & & $\mathrm{CS} 3$ & 0.802 \\
\hline \multirow[t]{3}{*}{ Financing Objectives } & \multirow[t]{3}{*}{0.841} & FO1 & 0.824 \\
\hline & & $\mathrm{FO} 2$ & 0.823 \\
\hline & & FO3 & 0.749 \\
\hline \multirow{4}{*}{$\begin{array}{l}\text { Familiarity/experience with } \\
\text { the target company or its } \\
\text { product }\end{array}$} & \multirow[t]{4}{*}{0.81} & FTC1 & 0.777 \\
\hline & & FTC2 & 0.734 \\
\hline & & FTC3 & 0.786 \\
\hline & & FTC4 & \\
\hline \multirow[t]{3}{*}{ Intention of use } & \multirow[t]{3}{*}{1} & IU1 & 1 \\
\hline & & IU2 & \\
\hline & & IU3 & \\
\hline \multirow[t]{3}{*}{ Number of Inquiries } & \multirow[t]{3}{*}{0.834} & NI1 & 0.827 \\
\hline & & NI2 & 0.705 \\
\hline & & NI3 & 0.836 \\
\hline \multirow[t]{3}{*}{ Number of Shares } & \multirow[t]{3}{*}{0.803} & NSA1 & \\
\hline & & NSA2 & 0.807 \\
\hline & & NSA3 & 0.831 \\
\hline \multirow[t]{4}{*}{ Target Attractiveness } & \multirow[t]{4}{*}{0.833} & TA1 & 0.806 \\
\hline & & TA2 & 0.883 \\
\hline & & TA3 & \\
\hline & & TA4 & \\
\hline
\end{tabular}

Based on the results of reliability testing in Table 6, it was found that all variables had a Composite Reliability value $>0.70$ so that all variables had passed the internal consistency reliability test. And it was found that all indicators had a loading value $>0.70$ so that all indicators had passed the reliability indicator test. 


\subsection{Coefficient Determination $\left(\mathbf{R}^{2}\right)$ \& Predictive Relevance $\left(Q^{2}\right)$ Test}

Table 7. Coefficient Determination $\left(\mathrm{R}^{2}\right)$ \& Predictive Relevance $\left(\mathrm{Q}^{2}\right)$ Test Result

\begin{tabular}{|l|c|c|c|c|}
\hline & RSquare & RSquare Adjusted & Note & QSquare \\
\hline Intention of Use & 0.280 & 0.270 & Weak & 0.241 \\
\hline
\end{tabular}

Based on Table 7, it is found that the value of the Coefficient of Determination adjusted for the Intention of Use variable is 0.270 , which means $27 \%$ of the Intention of Use variable can be explained by the Campaign Specification variable, Financing Objectives, Familiarity/experience with the target company or its product, Number of Inquiries, Number of Shares and Target Attractiveness. The remaining $73 \%$ will be explained by other variables apart from these variables. And also it is found that Intention of Use has a Q-Square value of 0.241. These results indicate the model's predictive accuracy has met the requirements because the Q-Square value is above 0 .

\subsection{Hypothesis Analysis}

Table 8. Hypothesis Testing Result

\begin{tabular}{|l|c|c|c|c|}
\hline $\begin{array}{c}\text { Relationship between } \\
\text { Variables }\end{array}$ & $\begin{array}{c}\text { Original Sample } \\
(\mathbf{O})\end{array}$ & $\begin{array}{c}\text { T-Statistics } \\
(\mid \mathbf{O} / \text { STDEV })\end{array}$ & P-Values & Note \\
\hline$F O \rightarrow I U$ & 0.134 & 1.568 & 0.117 & H1 Rejected \\
\hline$N S A \rightarrow I U$ & 0.039 & 0.561 & 0.575 & H2 Rejected \\
\hline$N I \rightarrow I U$ & -0.125 & 1.509 & 0.131 & H3 Rejected \\
\hline$F T C \rightarrow I U$ & 0.241 & 3.148 & 0.002 & H4 Accepted \\
\hline$T A \rightarrow I U$ & 0.231 & 3.274 & 0.001 & H5 Accepted \\
\hline$C S \rightarrow I U$ & 0.1 & 1.269 & 0.205 & H6 Rejected \\
\hline$F O \rightarrow I U$ & 0.134 & 1.568 & 0.117 & H1 Rejected \\
\hline
\end{tabular}

Based on the results of the hypothesis test presented in the Table 8, the following conclusions and analysis are obtained as follows:

- Analysis of Hypotesis 1 (H1). In the test results for Hypothesis 1, Financing Objectives on Intention of Use shows the p-value is greater than $0.05(0.114)$ and the t-statistics value is less than $1.96(1.583)$. So the Financing Objectives do not have a significant effect on Intention of Use. The test results are not in accordance with the results of previous research conducted by ( $\mathrm{Li}$ et al., 2018), which states that Financing Objectives have a significant effect on Intention of Use. Related to this, investors/users of the equity crowdfunding platform are not sure about the amount of funding targets, the amount of remaining funding needed and the minimum amount of initial funding submitted to the campaign which is carried out through the equity crowdfunding platform.

- Analysis of Hypothesis 2 (H2). In the test results for Hypothesis 2, Number of shares assigned on Intention of Use shows the p-value is greater than 0.05 (0.559) and the t-statistics value is smaller than $1.96(0.584)$. So the Number of shares assigned does not have a significant effect on Intention of Use. The test results are not in accordance with the results of previous research conducted by (Li et al., 2018), which states that Number of shares assigned has a significant effect on Intention of Use. Related to this, investors/users of the equity crowdfunding platform are not sure about the suitability of the amount/proportion of shares that will be obtained when funding through the equity crowdfunding platform to the amount of funds invested by investors/users of the equity crowdfunding platform.

- Analysis of Hypothesis 3 (H3). In the test results for Hypothesis 3, Number of Inquiries on Intention of Use, it shows that the p-value is greater than 0.05 (0.131) and the t-statistics value is less than $1.96(1.511)$. So the Number of Inquiries does not have a significant effect on Intention of Use. The test results are not in accordance with the results of previous research conducted by (Li et al., 2018), which states that Number of Inquiries has a significant effect on Intention of Use. This is related to this because investors/users of the equity crowdfunding platform are not sure about the information/availability of information obtained through the funding campaign carried out through the equity crowdfunding platform related to the existing funding projects on the equity crowdfunding platform.

- Analysis of Hypothesis 4 (H4). In the test results for Hypothesis 4, Familiarity/experience with the target company or its product on Intention of Use shows the p-value is less than $0.05(0.001)$ and the t-statistics value is greater than $1.96(3.206)$. So the Familiarity/experience with the target company or its product has 
a significant effect on Intention of Use. The test results are in accordance with the results of previous research conducted by (Lukkarinen et al., 2018), which states that Familiarity/experience with the target company or its product has a significant effect on Intention of Use. This is because investors/users of the equity crowdfunding platform feel confident about the company (and its products) that will be funded through the equity crowdfunding platform, including getting enough information and/or recommendations regarding the company and its products to investors/users of the equity crowdfunding platform.

- Analysis of Hypothesis 5 (H5). In the test results for Hypothesis 5, Target attractiveness on Intention of Use, it shows the p-value is less than 0.05 (0.001) and the t-statistics value is greater than 1.96 (3.266). So the Target attractiveness has a significant effect on Intention of Use. The test results are in accordance with the results of previous research conducted by (Lukkarinen et al., 2018), which states that target attractiveness has a significant effect on Intention of Use. This is because investors/users of the equity crowdfunding platform get enough information related to historical and financial forecasting from the companies that will be funded through the equity crowdfunding platform.

- Analysis of Hypothesis 6 (H6). In the test results for Hypothesis 6, Campaign Specification on Intention of Use, it shows the p-value is greater than 0.05 (0.213) and the t-statistics value is smaller than $1.96(1.246)$. So the Campaign Specification does not have a significant effect on Intention of Use. The test results are not in accordance with the results of previous research conducted by (Lukkarinen et al., 2018), which states that the Campaign Specification has a significant effect on Intention of Use. In this regard, it is because the specifications of the company to which the funding is submitted through the funding campaign on the equity crowdfunding platform are not able to convince investors/users of the equity crowdfunding platform.

\section{Conclusions and Recommendation}

\subsection{Conclusions}

Hypothesis testing show that the factors that influence the JABODETABEK community's decision to use (Intention to use) the equity crowdfunding platform are Familiarity/experience with the target company or its product, with a regression coefficient value of 0.241 and Target attractiveness with a regression coefficient value of 0.231 .

\subsection{Recommendation}

The authors suggest several alternatives to consider for further improvement.

- The equity crowdfunding platform can continue to maintain and improve campaigns with familiar companies and companies that have products/services that are familiar to the community and delivery related to the target attractiveness of the campaigns organized by the equity crowdfunding platform, so that it can further increase the interest of investors. Apart from that, the equity crowdfunding platform might also consider implementing the Artificial Intelligence system to filter information on non-performing loans from companies that are funded through the equity crowdfunding platform.

- Variable Intention to Use in this study is only affected by $28 \%$ by the variables contained in this study. So it is advisable to use other variables such as Subjective Norm and Security. and in future research, the author may consider doing research on other crowdfunding platforms.

\section{References}

[1]. Adriansyah, I. (2016). Perencanaan bisnis situs crowdfunding untuk pendanaan usaha startup bidang ekonomi kreatif.

[2]. Belleflamme, P., Lambert, T., \& Schwienbacher, A. (2014). Crowdfunding: Tapping the right crowd. Journal of Business Venturing, 29(5), 585-609. https://doi.org/10.1016/j.jbusvent.2013.07.003

[3]. Cenfetelli, R. T. (Sauder S. of B., \& Bassellier, G. (Desautels F. of M. (2015). Interpretation of Formative Measurement Interpretation Information Systems Research. 33(4), 689-707.

[4]. Ferreira, F., \& Pereira, L. (2018). Equity Based Crowdfunding Campaign. 2018 IEEE International Conference on Engineering, Technology and Innovation (ICE/ITMC), 1-8.

[5]. Hair, J. F., Ringle, C. M., \& Sarstedt, M. (2011). PLS-SEM: Indeed a silver bullet. Journal of Marketing Theory and Practice, 19(2), 139-152. https://doi.org/10.2753/MTP1069-6679190202

[6]. Hellmann, T. (2007). Entrepreneurs and the process of obtaining resources. Journal of Economics and Management Strategy, 16(1), 81-109. https://doi.org/10.1111/j.1530-9134.2007.00133.x

[7]. Hemer, J. (2011). A snapshot on crowdfunding. Enconstor, 39.

[8]. Henseler, J., Ringle, C. M., \& Sinkovics, R. R. (2009). The use of partial least squares path modeling in international marketing. Advances in International Marketing, 20(2009), 277-319. https://doi.org/10.1108/S1474-7979(2009)0000020014 
[9]. Li, Y., Cao, H., \& Zhao, T. (2018). Factors Affecting Successful Equity Crowdfunding. Journal of Mathematical Finance, 08(02), 446-456. https://doi.org/10.4236/jmf.2018.82028

[10]. Lukkarinen, A., Wallenius, J., \& Seppälä, T. (2018). Investor Motivations and Decision Criteria in Equity Crowdfunding. SSRN Electronic Journal, 11(August). https://doi.org/10.2139/ssrn.3263434

[11]. Majchrzak, A., Wagner, C., \& Yates, D. (2013). The impact of shaping on knowledge reuse for organizational improvement with Wikis. MIS Quarterly: Management Information Systems, 37(2), 455469. https://doi.org/10.25300/MISQ/2013/37.2.07

[12]. Nugroho, A. Y., \& Rachmaniyah, F. (2019). Fenomena Perkembangan Crowdfunding Di Indonesia. Ekonika : Jurnal Ekonomi Universitas Kadiri, 4(1), 34. https://doi.org/10.30737/ekonika.v4i1.254

[13]. Statistik, B. P. (2019). ANALISIS HASIL SE2016 LANJUTAN Potensi Peningkatan Kinerja Usaha Mikro Kecil (Vol. $53, \quad$ Issue http://publications.lib.chalmers.se/records/fulltext/245180/245180.pdf\%0Ahttps://hdl.handle.net/20.50 0.12380/245180\%0Ahttp://dx.doi.org/10.1016/j.jsames.2011.03.003\%0Ahttps://doi.org/10.1016/j.gr.20 17.08.001\%0Ahttp://dx.doi.org/10.1016/j.precamres.2014.12 